\title{
The "Business Schools" Programme, within the Framework of the Territorial Network of Support to the Entrepreneur in Andalusia (Spain)
}

\author{
Jaime de Pablo Valenciano $^{1}$, Juan Uribe Toril ${ }^{1}$, Jean Pierre Levy Mangin ${ }^{2}$ \\ ${ }^{1}$ University of Almería, Almería, Spain; ${ }^{2}$ University of Québec, Québec, Canada. \\ E-mail: \{jdepablo, juribe\}@ual.es, Jean-Pierre.Levy-Mangin@uqo.ca
}

Received April 16 ${ }^{\text {th }}, 2010$; revised June 19 ${ }^{\text {th }}, 2010$; accepted September $12^{\text {th }}, 2010$.

\begin{abstract}
The local government of Andalusia runs several public programmes, aimed at encouraging new business start-ups, and is responsible for stimulating the local economy. It is known that companies that have followed a business training programme and have the support of a specialized technical advisory service with a lower rate of failure. This presentation analyses the programmes that make up the map of existing mechanisms. One of these shall be studied in depth: The "Business Schools" programme; part of the Territorial Entrepreneur Support Network. "Business Schools" came into being in the early nineties and were designed to set up social economy companies in rural districts and encourage the settlement of people in those areas. The doctrine that indicates the synergies existing between companies that coexist in certain surroundings is extensive. A series of commercial links can be seen to be generated between companies included in this programme, harnessing the value, not only of this type of programme, but also of the companies themselves. We can therefore conclude that incubation in these centres provides the companies involved with certain common characteristics, which result in collaboration amongst them and a healthy tendency to participate in business cooperation projects.
\end{abstract}

Keywords: Andalusia, Local Economy, Business Schools Programme, Entrepreneur

\section{Introduction}

There is no unanimity of criteria when we refer conceptually to the process of business accommodation and several definitions have been proposed by international bodies in order to clarify the term business incubator.

Having the assessment of a specialised consultant, together with the synergies that are produced between companies located in the business creation centres (in-cubators), gives a competitive advantage which encourages companies to form business groups or clusters.

The birth of the support process to companies through incubation in business nurseries was initiated primarily in the United States. This phenomenon was developed later in the European Union, linked to either the public sector or universities and contained on numerous occasions within $\mathrm{R}+\mathrm{D}+\mathrm{i}$ programmes.

The differences between the North American and European models are noticeable, although their purpose and evolution converge, providing the registered companies with a greater level of business survival.

The first precedents of business incubators were created in the University environment in the United States, specifically in 1942, in Ithaca, New York. The Students Agencies Inc. was created to give an appropriate physical space where the student born companies began to work.

In 1946 the American Research Development was created in the Massachusetts Institute of Technology (MIT) in order to give support to emerging companies in this centre of the MIT, using the institution buildings.

The phenomenon multiplied during the 1950s in the Silicon Valley region, under the auspices of the University of Stanford and with the backing of the Technology Park which at that moment was beginning to see the light of day (Stanford Research Park).

This decade saw the transferral of the technology developed in the University to corporations, and the creation of new technology intensive businesses, principally in the electronics sector, was developed, promoting a spirit of enterprise between students and researchers.

Public funding for areas in which the universityindustry binomial came together was substantial.

Neither must it be forgotten that the main engine of incubation at that time was the experimentation in the 
search for new technologies, and in the midst of the cold war, that search was focused mainly on the armament and military sectors.

The first private experience of incubation, outside a university environment, was found in Batavia, a town close to New York.

The American company, Massey Ferguson Co. was declared bankrupt and left more than 2,000 workers unemployed. The buildings of this company, which covered over 250,000 square metres, were too extensive to be managed by just one company. This nursery concentrated mainly on companies in the industrial sector.

The first company to move into these facilities was a chicken breeder and before long the similarities between poultry incubation and business incubation emerged. It would seem that this coincidence is the reason for the term being used with this specific meaning.

In the 1970s, The National Science Foundation founded the first Technology Based incubator. The Small Business Administration created a programme of incubators and the National Business Incubation Association (NBIA) also came into being.

However, the real business incubator boom did not happen until the mid 1980s. The financing of incubators in the USA is usually mixed (public and private finance), although, as we have seen, in the beginning the programmes were paid for by the public sector. In Europe, the incubators have multiplied rapidly and have been, in most cases, made up of not-for-profit organisations [1]. According to a study by the OCDE in 1997 , only $13 \%$ of the incubators would be able to maintain their level of operations without public funding, $52 \%$ would be able to continue but with reduced services and $35 \%$ would not be able to maintain their current configuration without this type of financial support.

It was in the 1990s when the incubators began to turn to innovation sectors, concentrating on the creation of a new type of information technology business, the socalled "dot-com" industry, or emerging sectors such as biotechnology. Similarly, virtual incubators began to appear, where the term business accommodation came to refer to the provision of a space on the net, instead of a physical location.

Since their appearance, business nurseries have managed to provide an incentive for relations between universities and companies, generating models of urban development.

They have served to establish support networks and exchange of products, renovated buildings and urban areas, promote investment, consolidate companies and have given help to entrepreneurs who committed to the future [2].

\section{Business Incubator}

\subsection{Concept}

The following definitions of the business incubator can be highlighted:

The National Business Incubation Association (NBIA) defines business incubators as an economic development tool designed to accelerate the growth and success of enterprising companies through an arsenal of resources and support services to the company. The main objective of a business incubator is for companies to leave the programme independent and financially profitable.

UK Business Incubation refers to it as a dynamic business development process. It is a term which covers a wide variety of processes that help to reduce the percentage of problems a company faces in its early years and accelerates the growth of companies which have the potential to generate substantial employment and sales. The main characteristic of business incubators is that they have the ability to facilitate the grouping of small working units, to which they provide an instructive atmosphere, and give support to those entrepreneurs in the start-up phase during their early years. Incubators provide three main elements to the development of successful businesses: entrepreneurs and a learning environment, easy access to mentors and investors and finally, visibility and placement in the market.

The European Business Incubation Centres Network points out that incubators are support organisations for Small and Medium Sized Innovation Companies and entrepreneurs. They are set up by the main economic operators in an area or region of public interest, in order to offer a range of comprehensive management services and support projects carried out by the small and medium companies, thus contributing to local and regional development.

A common feature of all business incubators is that they are endowed with a space dedicated to the transfer of companies, encouraging the creation and consolidation of such companies.

These centres are usually characterised by their special ties with the university environment, specialisation in technology based companies and special attention to specific training.

The model to follow in Europe is that of North America, although we must take into account the intrinsic differences of the European Union and the lateness of the introduction of new Technologies [3].

When we consider business accommodation, we must take into account that there exist a multitude of terms which refer us to this phenomenon.

In fact, the term incubator in the United Kingdom is 
identified as much with nurseries (where the company still has to be formed) as with Business Centres; however, in France, the term incubator is only synonymous with business project nurseries (known as pre-incubators in Spain).

In this way, and in a wider sense, we can correlate the terms incubator, seed-bed and Business Centres as similar identifying factors.

The use of the terminology applied to these programmes (incubation) is not a trivial question. The name used to define this phenomenon is used in natural science as much as in the business world, representing a series of adjectives which describe: security, protection, acceleration, nutrition [4].

Technopoles, industrial estates, incubators, and science parks, can all be characterized by high rates of entrepreneurial activity and high-tech start-ups. However, they have often been accused of being artificial and expensive without contributing to the local economy. Evidence shows that such planned forms of enclaves create more global than local linkages [5].

\subsection{Types of Incubation}

There are two types of incubator, according to the sector on which they focus or the services which offered:

- Classic or General Incubators: Also called business centres, accommodating small to medium companyies, providing them with the basic infrastructure for their development at the initial stage of their activity.

- Industrial Nurseries: Contribute to local economic development through the creation of small industries.

- Export Centres: Dedicated to international marketing. The usual services are normally offered together with tax incentives.

- Virtual Incubators: Offer services in a virtual format, connecting companies and clients through technological platforms or other telecommunication media.

- Micro-enterprise Incubators: Promote the creation of companies in severely economically challenged areas, but with little possibility to develop into the mid to long terms. These areas are regions with high unemployment and subsistence problems, and which the private sector finds difficult to reach.

- Technological Incubators: Situated in Technology Parks, specialising in $\mathrm{R}+\mathrm{D}+\mathrm{i}$ and in providing support to Technology Based Companies (TBC) (Table 1).

The services which are offered to the incubated companies in these centres will vary depending on the characteristics of the managing body.

Tutoring (mentoring) in financial matters, marketing or specialised technical assistance is used in order to
Table 1. What's a technological incubator.

\begin{tabular}{ll}
\hline Example: & $\begin{array}{l}\text { Business International Incubator } \\
\text { (China) }\end{array}$ \\
\hline Technology level & Low and high \\
Skills & Medium \\
Innovation & Some \\
Trust & Little \\
Cooperation & Little \\
Competition & Medium \\
Size of firm & SME \\
Exports & Some \\
Learning & High \\
\hline
\end{tabular}

Source: Own data and UNCTAD [6]

provide a greater value to the incubator, in terms of long term business survival [7], although, the services offered are usually of a more basic and elementary assistance: renting of space, distribution of information, legal, technical and economic assessment, courses for entrepreneurs and little more [8].

For their part, the services most valued by the entrepreneurs are the initial savings on equipment, the company image and savings in the cost of rental and services. [9] and [10]

The time spent in an incubator provides clear advantages, above all during the initial stages of the company, allowing the entrepreneur to be less concerned about administrative, legal or financial problems and to be able to concentrate on his or her own business development [11]. Incubators can be defined as facilitating agents in the innovation process [12].

\section{The "Business School" Model as Incubator in Rural Environments}

\subsection{Origins and Evolution}

The "Business Schools" were born in 1990 under the Decree 131/1990 of the 8th of May, from the Regional Ministry of Development and Employment, in order to regulate the programme of "Business Schools" for Young people's Co-operatives and the Order of 3rd of July 1990 which developed it with the purpose of securing real opportunities for the integration of young people into the workplace.

This regulatory framework was based on trainingpromotion of employment programmes to encourage young people's co-operatives and dynamism of economic resources, promoted by local corporations or nonprofit making bodies (generally Town Halls).

In short, the mentioned bodies provided the site to the "Business Schools" (intended for the promotion of youth co-operatives), for the construction or adaptation of the 
centres facilities via the application of a grant to the then Regional Ministry of Development and Employment [13].

The facilities of the "Business Schools" which had started consisted of a minimum of four work centres for business incubation (generally industrial premises) and a management and assessment centre where a technician was responsible for training and consultancy. The Business Centres began their territorial expansion with a network of 40 centres distributed throughout the whole of Andalusia [14].

The funds for contracting personnel, as well as that of a company specialising in support to the "Business School" were transferred quarterly, previously verified. In the first modification to the model of the "Business School", five years after its start up, the term "young people's co-operative" disappeared and the companies that had been incubated had to be legally constituted as co-operatives or public limited companies, consisting of a majority of members under the age of 30 (it had previously been exclusively for those under the age of 25), making the accommodation of the self-employed possible.

The Andalusian Business School Foundation, which was created by the local government, will be the recipient of the overall grant aimed at these centres which will allow greater administrative flexibility and it will be responsible for the operational and economic control and management of the programme.

In 2001 there was a new turn of events. New centres were opened across the region, until there were more than 150 centres on the map, some without the capacity to incubate companies, acting as assessment and business processing offices.

In 2003, the "Business Schools", until that moment specialists in associated work co-operatives and work societies, moved on to legal assessment and tutelage.

As they have no equivalent, the "Business Schools" are classified according to their given infrastructure. As obligatory infrastructure, they all have an administration centre at their disposal, and technical and training support services to the companies [15].

Depending on the number of work centres linked to the office, that is to say, to the premises or offices dedicated to business accommodation, "Business Schools" with the capacity for incubation can be levels A, B and C, (the object of this study) and those that only have the minimum structure available, level D.

In 2007, the model has already gone through its final adjustment. The Innovation and Modernisation Plan for Andalusia, promoted by the local government, takes into account a series of proposals and strategic lines with the aim of strengthening the business culture, encouraging the creation of new companies and helping the entrepreneur.
The creation of a Territorial Support Network to the Entrepreneur is needed in this context, with the intention of integrating already existing regional support programmes to entrepreneurs in Andalusia ("Business Schools", Support Centres to Business Development, virtual nurseries...) as well as support infrastructures for entrepreneurial activity and other specialised assessment tools. The programme of "Business Schools" will go on to accommodate and lead this network.

\subsection{The Internationalisation of the "Business School" Programme}

The success of the programmes managed by the Foundation, with important repercussions in terms of generation of stable employment and local economic development, has aroused the interest of not only other (Spanish) Autonomous Communities, but also other countries within the European Union.

Through its integration in the European Networks for the development of common projects and the exchange of experiences in the community setting (remembering to include the term network in the name of the foundation) different international projects have been promoted.

In the same way, this success has allowed its exportation to Central America (El Salvador, Panama and Guatemala) and Morocco, where "Business Schools" are being built and already working through programmes of co-operation for development established by the Local Government of Andalusia [16].

In Panama, the "Business School" programme is developed by the Ministry of Employment and Labour Development with the technical and financial assistance of the Regional Government of Andalusia, and two schools in the towns of Colon and San Miguelito have been made available for the young people of Panama, in order to generate productive employment through the creation of micro-companies.

The construction of the Schools was completed on the 14th of June 2000 and its modus operandi is exactly the same as the Andalusian programme.

In El Salvador, the Local Development and Social Investment Fund (LDSIF), has operated the "Business Schools" (encouraged and financed by the Regional Government of Andalusia) since May 1997 in the cities of Sonsonate and Nejapa.

The initial tangible result of this co-operation has been six micro-enterprises, together giving employment to more than 40 Salvadorians.

Ever since the project was conceived, the general objective was to contribute to the rise in productive material of El Salvador facilitating the decentralisation of production, the creation of co-operatives and viable micro-enterprises.

The strength of the "Business Schools" is their teaching 
method, which consists of learning on the job; that is to say, a vocational professional training, whose exercises and practical tasks are: to integrate co-operatives and micro-companies, present economically and financially viable technical business projects.

Also, in Guatemala steps have been taken to install another centre of this type in the town of Zacapa.

In Morocco, two other "Business Schools" are currently working in the cities of Beni Makada, in the province of Tangiers and Sidi el Mandri, in Tetuan, with an overall budget of one million euros, $79 \%$ of which is provided by the Local Government of Andalusia.

\subsection{Degrees of Links of the Companies with the Programme}

Companies become contractually linked to the "Business Schools" by way of affiliation, being able to profit from the technical assistance offered by them and, in some cases, to be transferred from the modules or premises allocated for business incubation.

Depending on their characteristics and the services applied for, the accepted companies are classified as:

- Comprehensive Companies.

These generally take the shape of a partnership, generators of employment at the moment of affiliation to the programme and whose economic activity takes advantage of the endogenous resources implementing local development.

They enjoy all the rights and obligations stipulated by the programme. A formative itinerary is prepared for them and included in their affiliation contract for the duration of the programme. This method of affiliation is obligatory for incubated companies.

- Associated Companies.

Companies which are not accommodated in the facilities of the "Business Schools" but wish to be linked contractually in order to have access to technical assistance and training are included within this category. The follow-up that is carried out is reduced and an initial formative plan is not made, although they are able to participate in this type of work.

- Support Companies.

These are entrepreneurs or companies covered by any information or administration needs which may be either specific or periodic.

They do not have affiliation contracts with the "Business Schools" Programme, nor are they covered by the regulation order.

\subsection{Incubated Companies vs. Assessed Companies; Differences in Progress (Variance Analysis)}

The database used for the study contains a total of 14,580 entries up to the 31st of December 2009, between the eight provinces of Andalusia.

The items correspond to companies or business projects, regardless of the affiliation process, even those which did not complete their application or applied to leave the programme.

To purge the data and work with a representative sample, a series of filters were employed.

An initial selection was made in which only companies whose registered offices were in the Province of Almería were chosen, reducing the sample from 14,580 entries to 1,534 possible questioned users.

Those entries marked as "invalid" were eliminated, which implies that the collected data does not give the true picture because of a system error and the entrepreneurs who did not fulfil the procedures for company creation.

The consequence was a reduction in the number of surviving entries to 1,475 .

In order to restrict ourselves to a homogenous group of companies registered in the programme, we must eliminate those who do not benefit from all the services that a School can offer (support companies).

The number of companies was narrowed down to a total of 287.

We cannot consider those companies which have applied to leave the programme or those whose Technical Manager considers ready to leave.

Consequently, we are left with 240 companies with the potential to participate in the survey.

The final filter chosen is the timescale. With the aim of not limiting ourselves to the timescale of the programme (three years), we have selected a longer period of four years, 2003-2006, the final number of companies suitable for participating in the survey being $142.74 .6 \%$ of these companies agreed to answer a set of questions.

The sector of activities of the companies (Table 2) is divided between industry and services. The reason for this is twofold; firstly, because the allocation of industrial premises determines that the applicants are industrial and therefore the "Business Schools" have paid more attention to projects dedicated to industry.

Secondly, the local administration upon which the "Business Schools" depend has had responsibility with regard to industry.

In order to determine the size of the companies studied we have looked at two variables: the number of workers (Table 3 ) and the average turnover in the final year (Table 4).

With regard to the number of workers, including partners, the average was placed in a band of approximately 3 to 5 workers.

As for turnover, we encounter a wide range, from 0 to 300,000 euros, not obtaining an equal criteria, which indi- 
cates that there are companies which are starting their activity and having a poor turnover facing established companies with high levels of revenue and capital. Through variance analysis we intend to verify whether significant differences in turnover exist between the integrated and affiliated companies, which only receive assessment and /or training, during the three years that they spend in the programme.

Regarding the purged database of companies (106 firms), the accommodated companies have been separated from those which have not received incubation but have been assessed by the network technicians (associated companies) and the turnover data of both groups has been collected. It is to be expected that affiliation with accommodation in a "Business School" improves results.

In order to prove this we calculate the intervals of confidence (Table 5 and Graph 1) a make a variance analysis of the data. Intervals are calculated by the LSD method.

As can be seen, the average of growth in the 3 years of registration to the programme for the incubated companies $(3.82 \%)$ is far superior to the average of the other companies $(0.31 \%)$.
The variance analysis endorses the direct observation (Table 6): significant differences exist between the two groups, so that we can conclude that the incubated companies improve their results in comparison with the free companies.

\section{Conclusions}

We would like to know if relevant economic differences exist between companies which benefit from business assessment and training provided by a technical assessor with respect to those which receive this treatment as well as the allocation of space in the incubator.

- First of all we check if the group of companies studied is consistent with respect to the variables: sector of activity, company size and number of workers.

- We discovered that the group is consistent within two parameters: more than $70 \%$ of the companies belonging to the industrial or services sectors (including new technologies) and with respect to the number of employees, more than $88 \%$ have fewer than 6 workers.

- However, regarding the levels of turnover we find a wider dispersal.

Table 2. Sector of activity.

\begin{tabular}{llcccc}
\hline & Frequency & Sample percentage & Valid percentage & Accumulated percentage \\
\hline \multirow{6}{*}{ Group } & Agriculture & 2 & 1.88 & 1.88 & 1.89 \\
& Food & 3 & 2.83 & 2.83 & 4.72 \\
& Commerce & 4 & 3.77 & 3.77 & 8.49 \\
& Construction & 21 & 19.81 & 19.81 & 28.30 \\
& Industry & 32 & 30.18 & 30.18 & 58.48 \\
& Services & 34 & 32.07 & 32.07 & 90.55 \\
& New Technologies & 10 & 9.43 & 9.43 & 100 \\
\hline
\end{tabular}

Source: Own data.

Table 3. Number of employees.

\begin{tabular}{llcccc}
\hline & & Frequency & Percentage & Valid percentage & Accumulated percentage \\
\hline \multirow{4}{*}{ Range } & $1-3$ & 45 & 42.45 & 42.45 & 42.45 \\
& $4-6$ & 49 & 46.22 & 46.22 & 88.67 \\
& $7-10$ & 7 & 6.60 & 6.60 & 95.27 \\
TOTAL & More than 10 & 5 & 4.71 & 4.71 & 100 \\
\hline
\end{tabular}

Source: Own data.

Table 4. Turnover.

\begin{tabular}{llcccc}
\hline & Frequency & Percentage & Valid percentage & Accumulated percentage \\
\hline \multirow{6}{*}{ Range } & $0-30.000 €$ & 19 & 17.92 & 18.26 & 18.26 \\
& $30,001 €-60,000 €$ & 21 & 19.81 & 20.19 & 38.45 \\
& $60,001 €-150,000 €$ & 36 & 33.96 & 34.61 & 73.06 \\
& $15,000 €-300,000 €$ & 16 & 15.09 & 15.38 & 98.44 \\
& $300,001 €-600,000 €$ & 9 & 8.49 & 8.65 & \\
& Over $600,000 €$ & 3 & 2.75 & 2.88 & 100 \\
\hline
\end{tabular}

Source: Own data. 
Table 5. Description of the data and intervals.

\begin{tabular}{cccccc}
\hline Type & Cases & Average & $\begin{array}{c}\text { Typical } \\
\text { variation }\end{array}$ & Lower limit & $\begin{array}{c}\text { Upper } \\
\text { limit }\end{array}$ \\
\hline 1 & 18 & 3.84333 & 0.504973 & 3.135 & 4.551 \\
2 & 88 & 0.315795 & 0.228383 & -0.004 & 0.636 \\
TOTAL & 106 & 0.914811 & & & \\
(1) Incubated companies. & (2) Other companies. \\
\hline
\end{tabular}

Source: Own data.

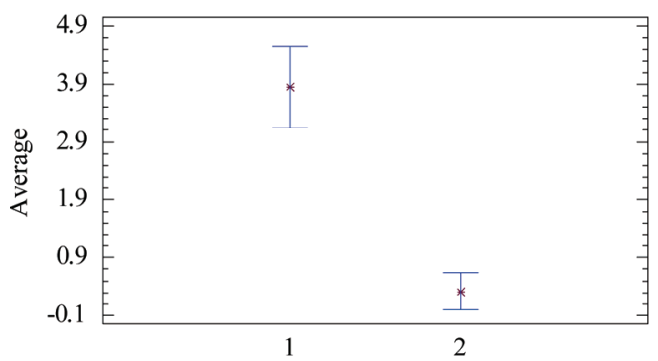

(1) Incubated Companies. (2) Other Companies.

Intervals calculated by LSD method. Source: Own data.

Graph 1. Representation of intervals.

Table 6. Description of the data and intervals.

\begin{tabular}{lccccc}
\hline & $\begin{array}{c}\text { Sum of } \\
\text { Tables }\end{array}$ & g.l & $\begin{array}{c}\text { Sq. } \\
\text { Measured. }\end{array}$ & F-Ratio & P-Value \\
\hline Between Groups & 185.949 & 1 & 185.949 & 40.51 & 0.0000 \\
Within Groups & 477.356 & 104 & 4.589 & & \\
Total & 663.304 & 105 & & & \\
\hline
\end{tabular}

g.l. $=$ degrees of freedom.

Source: Own data.

- Separating the incubated companies from the nonincubated companies, we confirmed, by means of variance analysis that, a significant difference does exists between both groups with respect to the levels of turnover during a period of three years.

We can state that this study confirms the hypothesis that the business incubation process has direct economic repercussions on the turnover of the accommodated companies in contrast to those which do not receive accommodation.

"Business Schools" are a consistent tool for giving technical support to newly-formed companies.

\section{REFERENCES}

[1] R. Aernoudt, "Incubators: Tool for Entrepreneurship?" Small Business Economics, Vol. 23, No. 2, 2002, pp. 127135.

[2] J. Camacho, "Incubators or Technology Based Company Nurseries: The Recent European Experience as a Current Work of Reference and for Future Latin-American Initiatives," XII Latin-American Congress on the Spirit of Enterprise, Incubation of Technology Based Companies and Technology Parks, Area, 1998.
[3] F. Fuentes, "Growth, Technology and Financing," ICE Bulletin, No. 2664, 2000, pp. 29-40.

[4] P. D. Hannon, "A Qualitative Sense-Making Classification of Business Incubation Environments," Qualitative Market Research: An International Journal. Vol. 7, No. 4, 2004, pp. 274-283.

[5] Organisation for Economic Co-Operation and Development, "Local Development and Business Incubators: Experiences on Enterprise and Job Creation, Local Economic and Employment Development," OECD Publications, 1997.

[6] United Nations, "Promotion and Sustaining SMEs Cluster and Networks for Development," United Nations Conference on Trade and Development, Expert Meeting on Clustering and Networking for SME Development, Geneva, September 1998.

[7] G. Udell, "Are Business Incubator Really Creating New Jobs by Creating New Businesses and New Products," Journal of Production Innovation Management. Vol. 7, No. 2, 1990, pp. 108-122.

[8] F. Marimon and J. M. Alonso Martínez, "Company Nurseries in Catalonia - Traditional and Specialised," Economic Bulletin for the ICE, No. 2860, 2005, pp. 31-46.

[9] J. A. Belso, "Public Performance and New Companies: a Specific Policy on Behalf of the Figure of the Entrepreneur at the Moment of Creation," Ph.D. Dissertation. Department of Economic and Financial Studies. Faculty of Social Science and Legal Studies, Miguel Hernández University, Elche, 2002.

[10] P. Escorsa and J. Valls, "Technology and Innovation in the Company," Polytechnic University of Catalonia and the Latin-American States Organisation for Education, Science and Culture (LSO), 2002.

[11] A. Maroto and A. García, "The Business Incubation Phenomenon and the CEEIS," Work Document No. 4/2004, 2004, University Institute of Social and Economic Analysis, Alcalá de Henares Universtiy.

[12] M. Villanueva, "Basic Introductory Guide to the Spanish System of Science-Technology-Business," Published by the Spanish Federation of Innovation and Technology, 1999.

[13] The Andalusian Social Economic Foundation Network, "Network Report 2002," Regional Ministry for Employment and Technological Development Publication, 2003.

[14] The Andalusian Social Economic Foundation Network "The Andalusian Social Economic Foundation Network Report 2003," The Regional Ministry of Innovation, Science and Business Publication, 2004

[15] The Andalusian Social Economic Foundation Network, "The Andalusian Social Economic Foundation Network Report 2004," The Regional Ministry for Innovation, Science and Business Publication, 2005.

[16] N. Belmonte and R. Arbide, "Manage and Share Information Efficiently," Communication in Technimap, Civil Service Publications, 2004. 